\title{
SAMPUS, MELTUMP and THIMUMP - Diagnostic Categories Characterized by Uncertain Biological Behavior
}

\author{
SAMPUS, MELTUMP a THIMUMP - diagnostické kategorie \\ charakterizované nejistým biologickým chováním
}

\author{
Roncati L. ${ }^{1,2}$, Piscioli F. ${ }^{2}$, Pusiol T. ${ }^{2}$ \\ 'Department of Diagnostic and Clinical Medicine and of Public Health, Institute of Pathology, University of Modena and Reggio Emilia, Modena, Italy \\ 2 Provincial Health Care Services, Institute of Pathology, Santa Maria del Carmine Hospital, Rovereto, Italy
}

\begin{abstract}
Summary
In the dermatopathological practice, there is a group of atypical melanocytic lesions with borderline histological features between benign simulants and malignant melanoma (MM), due to conflicting diagnostic criteria and inter-observer disagreement. In these cases, the dermatopathologist is authorized to seek consult with an established expert in the field, but even the most experienced specialist may not be sure about the correct diagnosis and the subsequent biological behavior. There is general consensus among qualified dermatopathologists that can be helpful to insert these ambiguous cases into two diagnostic categories: SAMPUS (Superficial Atypical Melanocytic Proliferations of Unknown Significance) and MELTUMP (MELanocytic Tumors of Uncertain Malignant Potential). According to the conception of MM progression through two phases, the radial growth phase and the vertical growth phase, it is possible to identify a novel subtype of thin melanoma (THIM) with uncertain metastatic potential, due to the presence of extensive regression ( $\geq 75 \%$ of the lesion volume), which we here define with the acronym THIMUMP (THIn Melanoma of Uncertain Metastatic Potential) for the first time in literature.
\end{abstract}

Key words

malignant melanoma - thin melanoma - histology

Souhrn

V dermatopatologické praxi existuje skupina atypických melanocytárních lézí s hraničními histologickými rysy mezi benigními lézemi, podobnými melanomu, a maligním melanomem $(M M)$, při konfliktních diagnostických kritérích a při rozporech mezi jednotlivými vyšetřujícími. $V$ těchto prípadech je dermatopatolog oprávněn konzultovat s odborníkem v oboru, ale ani nejzkušenější odborník si nemusí být jistý, zda byla stanovena správná diagnóza a následné biologické chování. Existuje obecná shoda mezi kvalifikovanými dermatopatology, která může pomoci zařadit tyto nejasné př́pady do dvou diagnostických kategorií: SAMPUS (superficiální atypická melanocytární proliferace nejasného významu) a MELTUMP (melanocytární nádory nejistého maligního potenciálu). Podle koncepce dvoufázové progrese MM, fáze radiálního růstu a fáze vertikálního růstu, je možné identifikovat nový podtyp tenkého melanomu (THIM) $s$ nejistým metastatickým potenciálem $v$ důsledku př́tomnosti rozsáhlé regrese $(\geq 75 \%$ objemu lézí), které zde poprvé v literatuře definujeme pomocí zkratky THIMUMP (tenký melanom nejistého metastatického potenciálu).

Klíčová slova

maligní melanom - tenký melanom - histologie
The authors declare they have no potential conflicts of interest concerning drugs, products, or services used in the study.

Autoři deklarují, že $v$ souvislosti s predmětem studie nemaji žádné komerční zájmy.

The Editorial Board declares that the manuscript met the ICMJE recommendation for biomedical papers.

Redakční rada potvrzuje, že rukopis práce splnil ICMJE kritéria pro publikace zasílané do biomedicínských časopisů.

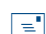

Dr. Luca Roncati, MD, PhD Department of Diagnostic and Clinical Medicine and of Public Health Institute of Pathology University of Modena and Reggio Emilia

Policlinico Hospital

I-41124 Modena (MO), Italy e-mail: emailmedical@gmail.com

Submitted/Obdrženo: 23. 4. 2017 Accepted/Přijato: 18. 5. 2017

doi: 10.14735/amko2017221 
In the dermatopathological practice, there is a group of atypical melanocytic lesions with borderline histological features between benign simulants and malignant melanoma (MM), due to conflicting diagnostic criteria and interobserver disagreement $[1,2]$. In these cases, the dermatopathologist is authorized to seek consult with an established expert in the field, but even the most experienced specialist may be not ensured about the correct diagnosis and the subsequent biological behavior [3]. There is general consensus among qualified dermatopathologists that can be helpful to insert these ambiguous cases into two diagnostic categories: SAMPUS (Superficial Atypical Melanocytic Proliferations of Unknown Significance) and MELTUMP (MELanocytic Tumors of Uncertain Malignant Potential) [2,4]. However, some authors have criticized the descriptive provisional value of these diagnostic categories, related to the use of uncertain terminology; therefore, the terms are not universally accepted $[5,6]$. All primary MMs with a Breslow's depth $\leq 1 \mathrm{~mm}$ are defined as thin melanomas (THIMs), while those $>1 \mathrm{~mm}$ as thick melanomas $[7,8]$. According to the conception of MM progression through two phases [9], the radial growth phase (RGP) and the vertical growth phase (VGP), it is possible to identify a novel subtype of THIM with uncertain metastatic potential, due to the presence of extensive regression ( $\geq 75 \%$ of the lesion volume), which we define with the acronym THIMUMP (THIn Melanoma of Uncertain Metastatic Potential) for the first time in literature.

\section{SAMPUS}

SAMPUS category includes $\leq 1 \mathrm{~mm}$ thick lesions, in which the distinction lies between in situ or THIM and non-tumorigenic epidermal, junctional and/or papillary dermal melanocytic proliferations, such as atypical solar lentigo, junctional or superficial compound dysplastic nevus, pigmented spindle cell nevus of Reed. In these cases, mitoses and tumorigenic dermal growth are absent and, consequently, the lesion is not associated with competence for metastases. The prognosis is excellent and a wide excision is the curative treatment of choice; if the lesion is not excised, it locally persists and it may evolve towards a frank malignant lesion [1,10].

\section{MELTUMP}

MELTUMP category includes dermal melanocytic proliferations $>1 \mathrm{~mm}$ in depth that exhibit ill-defined features indicative of possible malignancy, potentially capable of metastatic events, such as atypical Spitz nevus, also designated as Spitz Tumor with Uncertain Malignant Potential (STUMP), pigmented spindle cell nevus with dermal atypia, minimal deviation $M M$, pigmented epithelioid melanocytoma, atypical blue nevi, dysplastic nevi with dermal atypia, some deep penetrating nevus $[1,10]$. It is a provisional diagnosis since a definitive diagnosis is not possible at initial presentation, and a long-term clinical follow-up is the only true evidence, in order to clarify its biological behavior. In fact, in these cases, a diagnosis of tumorigenic MM cannot be excluded, due to the presence of increased mitotic activity and cytologic atypia; for this reason, an expert evaluation and an aggressive management with a wide excision, suited for a possible $M M$, are required, including sentinel lymph node biopsy (SLNB) $[1,10]$. The above mentioned histological and behavioral ambiguities also reflect molecular aberrations [11], suggesting that these tumors represent a biological entity apart from conventional MM and melanocytic nevus.

\section{THIMUMP}

As already stated, two phases of MM growth are scientifically recognized: RGP and VGP. Following this conception, THIM may be classified into three subtypes.

I. Non-metastasizing THIM in RGP ( $\leq 1 \mathrm{~mm}$ in depth): the lesion is characterized by invasion of papillary dermis; there is no evidence of proliferation or tumor node formation; mitoses and regression are absent; a wide excision is the curative treatment of choice, exactly as for SAMPUS; SLNB is not indicated [12-14].

II. Metastasizing THIM in VGP ( $\leq 1 \mathrm{~mm}$ in depth): the lesion is associated with a statistical chance for distant metasta- ses; a dominant expansive tumor nest of 25-50 cells, largest than any nest within the epidermis, is present in the papillary dermis; mitoses are observable and should be enumerated, employing the "hot spot" method; a wide excision and SLNB are mandatory [15-17].

III. THIM of uncertain metastasizing potential ( $\leq 1 \mathrm{~mm}$ in depth): the lesion is characterized by extensive regression ( $\geq 75 \%$ of the tumor volume); it is burdened by a significant risk for metastasis, due to the presence of regression, which could contain a VGP clone; a wide excision is mandatory and SLNB is recommended $[18,19]$.

In conclusion, the diagnostic categories here illustrated, even if characterized by an uncertain biological behavior, allow to identify risk categories, which deserve a radical and careful patient management.

\section{References}

1. Pusiol T, Piscioli F, Speziali L et al. Clinical features, dermoscopic patterns, and histological diagnostic model for melanocytic tumors of uncertain malignant potential (MELTUMP). Acta Dermatovenerol Croat 2015; 23(3): 185-194.

2. Cerroni L, Barnhill R, Elder D et al. Melanocytic tumors of uncertain malignant potential: results of a tutorial held at the XXIX Symposium of the International Society of Dermatopathology in Graz, October 2008. Am J Surg Pathol 2010; 34(3): 314-326. doi: 10.1097/PAS.0b013e3181cf7fa0. 3. Piscioli F, Pusiol T, Roncati L. Diagnostic approach to melanocytic lesion of unknown malignant potential. Melanoma Res 2016; 26(1): 91-92. doi: 10.1097/ CMR.0000000000000215

4. Piscioli F, Pusiol T, Roncati L. Diagnostic disputes regarding atypical melanocytic lesions can be solved by using the term MELTUMP. Turk Patoloji Derg 2016; 32(1): 63-64. doi: 10.5146/tjpath.2015.01330.

5. Hurt MA. Diagnosis! (not prognosis, not potential, not risk). Am J Dermatopathol 2009; 31(8): 763-765. doi: 10.1097/DAD.0b013e3181bbc717.

6. Hookerman BJ. Dermatopathology: an abridged compendium of words. A discussion of them and opinions about them. Part 7 (M-O). Dermatol Pract Concept 2015; 5(1): 1-9. doi: 10.5826/dpc.0501a01.

7. Roncati L, Piscioli F, Pusiol T. Sentinel lymph node in thin and thick melanoma. Klin Onkol 2016; 29(5): 393-394.

8. Roncati L, Piscioli F, Pusiol T. Current controversies on sentinel node biopsy in thin and thick cutaneous melanoma. Eur J Surg Oncol 2017; 43(2): 506-507. doi: 10.1016/j.ejso.2016.09.014.

9. Roncati L, Pusiol T, Piscioli F. Thin melanoma: a generic term including four histological subtypes of cutaneous melanoma. Acta Dermatovenerol Croat 2016; 24(4): 169-174

10. Roncati L, Piscioli F, Pusiol T. Clinical application of the unifying concept of cutaneous melanoma. Chonnam Med J 2017; 53(1): 78-80. doi: 10.4068/cmj.2017.53.1.78. 11. Gerami P, Scolyer RA, Xu X et al. Risk assessment for atypical spitzoid melanocytic neoplasms using FISH to identify chromosomal copy number aberra- 
tions. Am J Surg Pathol 2013; 37(5): 676-684. doi: 10.1097/PAS.0b013e3182753de6.

12. Piscioli F, Pusiol T, Roncati L. Nowadays a histological sub-typing of thin melanoma is demanded for a proper patient management. J Plast Reconstr Aesthet Surg 2016 69(11): 1563-1564. doi: 10.1016/j.bjps.2016.08.026. 13. Roncati L, Pusiol T, Piscioli F. Up-to-date proposal for a histologic subcategorization of thin melanomas. Adv Anat Pathol 2017. doi: 10.1097/PAP.00000000000 00148.
14. Piscioli F, Pusiol T, Roncati L. Wisely choosing thin melanomas for sentinel lymph node biopsy. J Am Acad Dermatol 2017; 76(1): e25. doi: 10.1016/j.jaad.2016.08.069. 15. Roncati L, Piscioli F, Pusiol T. Surgical outcomes reflect the histological types of cutaneous malignant melanoma. J Eur Acad Dermatol Venereol 2016. doi: 10.1111/jdv.14023. 16. Piscioli F, Pusiol T, Roncati L. Thin melanoma subtyping fits well with the American Joint Committee on Cancer staging system. Melanoma Res 2016; 26(6): 636
17. Piscioli F, Pusiol T, Roncati L. Higher predictive value of sentinel lymph node biopsy in patients with histological subcategorization of thin melanoma. Int J Dermatol 2017. 56(5): e93-e94. doi: 10.1111/ijd.13548.

18. Piscioli F, Pusiol T, Roncati L. Critical points of T1 stage in primary melanoma. Melanoma Res 2017. doi: 10.1097/CMR.0000000000000357.

19. Piscioli F, Pusiol T, Roncati L. Histopathological determination of thin melanomas at risk for metastasis. Melanoma Res 2016; 26(6): 635.

\section{SOUTY̌̈̌ NA PODPORU AUTORSKÝCH TÝMŮ PUBLIKUJÍCICH V ZAHRANIČNÍCH ODBORNÝCH TITULECH}

\section{Odměna pro vítěze: 10000 Kč}

\section{Cíl soutěže:}

Podpořit renomé a prestiž časopisu Klinická onkologie - oficiálního časopisu ČOS ČLS JEP - u domácích i zahraničních autorů, lékařủ a akademických pracovníků.

\section{Podmínky soutěže:}

1. Soutěž je určena autorským týmům, které publikují v zahraničních odborných titulech.

2. Do soutěže budou zařazeny práce publikované v zahraničních titulech od ledna do prosince 2017.

3. Ve svých článcích zaslaných k publikaci do zahraničního periodika budou autoři citovat práci, která byla otištěna v časopise Klinická onkologie (k vyhledání lze použít databáze www.pubmed.org nebo www.linkos.cz).

4. Do soutěže nebudou zařazeny autocitace.

5. Ze všech prací, které splní podmínky soutěže, bude redakční radou vylosována jedna, jejǐž autorský tým bude oceněn částkou 10000 Kč.

\section{KLINICKÁ ONKOLOGIE

